\title{
Clifford Trusts: Use of Partnership Interests as Corpus; Leaseback
}

\section{Arrangements}

\author{
Charles W. Froehlich, Jr.*
}

HE GRANTOR of a "Clifford"1 trust is an individual who approaches
financial planning for the family with an eye to income tax savings." The trust is used for the purpose of shifting income and the tax thereon from the grantor to some other family member. This is accomplished without a permanent release of the property by the grantor since the term of the trust is limited, the corpus reverting to the grantor at the end of the term. The most popular uses of the Clifford trust have been to provide income for the support of needy relatives, and to generate income for the benefit of children. ${ }^{3}$

* A.B. 1951, Stanford University; LL.B. 1956, University of California. Acting Professor of Law, University of California, Berkeley.

1 The nane "Clifford" is derived from Helvering v. Clifford, 309 U.S. 331 (1940), the landmark case requiring inclusion by the grantor of the income of a short term trust on the basis of his retention of substantial elements of control over the trust corpus and income. Internal Revenue Code of $1954 \S \S 671-78$ deal primarily with the problems raised by the Clifford case, and are often referred to as the "Clifford" sections. In common parlance today a "Clifford" trust is a short term trust designed to comply with all the requirements of $\$ \S 671-78$, so that the income of the trust will be taxed either to the trustee or to the bencficiary and not to the grantor, as was the result in Helvering v. Clifford, sttpra.

2 The Clifford trust is primarily an income tax planning device, since the retention by the grantor of a reversionary interest in the corpus results only in a bimited reduction of his estate for death tax purposes. See INT. Rev. CoDE of 1954 \$§ 2031(a), 2033. Since the income from the assets during the trust period goes to the beneficiary, it does not augment the grantor's estate, and to this extent the trust serves an estate planning purpose. One whose interest in reducing death taxes equals his income tax concern, however, should utilize trust planning which can remove the reversion from the estate of the grantor. For this reason it has been suggested that the Clifford trust should be used neither by the rich, nor by the poor (since the poor usually do not have severe income tax problems), but by a rather narrow in-between group. See, e.g., Johnson, Trusts and the Grantor, 36 TAxrs 869, 872; Miller, Appropriate Forms of Gifts to Minors, N.Y.U. 16TH INST. ON FED. TAX 765, 767-68 (1958). Mr. Miller suggests that the appropriate donor for a Clifford trust for the benefit of children is one possessing not less than $\$ 100,000$ and not more than $\$ 500,000$ in liquid assets. It is quite likely, lowever, that the practitioner will encounter individuals in high income tax brackets who have far less than $\$ 100,000$ in liquid assets, and are nevertheless interested in establishing short term trusts for their children or other dependents. For some computations showing the tax advantages in typical situations where Clifford trusts are used, see Drew, Paying Family Expenses and Saving Taxes, 37 Taxes 689 (1959).

3 For general discussion of the use of Clifford trusts for the benefit of dependents, see Ehrlich, The Effective Use of Support Trusts, N.Y.U. 19rH Ivsr. ON FED. Tax 729 (1961); Ervin, Income, Estate and Gift Tax Problems in Planning Family Trusts Under the 1954 Internal Revenue Code, 29 So. CAI. L. REv. 1 (1955); Miller, Appropriate Forms of Gifts to Minors, N.Y.U. 16TH Inst. on Fed. TAX 765 (1958); Savage, Comparative Advantages 
The Clifford trust became a dependable planning tool with the advent of the Internal Revenue Code of $1954,{ }^{4}$ which resolved much of the confusion that had beset the draftsmen of short term trusts. Prior to 1954 the issues found most critical to the validity of the trust for tax purposes concerned the extent of "dominion and control" retained by the grantor over the trust corpus or income. The 1954 Code provides relatively clear standards for determining the extent to which dominion and control may be retained. ${ }^{5}$ Decisions must be made in drafting a

and Disadvantages of Support Trusts and Uniform Gifts to Minors Statute Gifts; What Constitutes Support, for Tax Purposes, N.Y.U. 17TH InsT. on FED. Tax 1097 (1959); Yohlin, The Short-Term Trust-A Respectable Tax-Saving Device, 14 TAx L. REv. 109 (1958). An interesting question facing draftsmen today is the extent to which support responsibilities of the grantor may be satisfied by trust income without attribution of the income so used to the grantor for tax purposes. Section 677(a) of the 1954 Code provides that a grantor will be treated as the owner of any portion of a trust the income from which is or nnay be "distributed" or "held or accumulated for future distribution" to him. Where trust income is utilized for the discharge of the grantor's legal obligation, it is deemed "distributed" to him. See Old Colony Trust Co. v. Counmissioner, 279 U.S. 716 (1929); Douglas v. Willcuts, 296 U.S. 1 (1935); Helvering v. Stuart, 317 U.S. 154 (1942). If the income distribution is for the purpose of paying for the college education of the grantor's dependent, therefore, it is taxable to the grantor to the extent that the obligation to pay for the college expenses constitutes his "legal obligation." The measure of the parent's "legal obligation" is to be found in local rather than federal law. Treas. Reg. $\$ 1.662$ (a) -4 (1946). For examples of determination by a federal court of the extent of the support obligation under local law, and the resulting determination of the extent to which trust income slould be taxable to the grantor, see Hamiel's Estate v. Commissioner, 253 F.2d 787 (6th Cir. 1958);. Hopkins v. Commissioner, 144 F.2d 683 (6th Cir. 1944); Mairs v. Reynolds, 120 F.2d 857 (8th Cir. 1941); Commissioner v. Grosvenor, 85 F.2d 2 (2d Cir. 1936). Discussions of this problem can be found in the articles cited above and also in the following: Goodson, Parent's Legal Obligation?, 99 TrUSTs \& Estates 17 (1960); Pedrick, Familial Obligations and Federal Taxation: A Modest Suggestion, 51 Nw. U.L. REv. 53 (1956); Tomlinson, Support Trusts and Gifts to Minors, 97 Trusts \& Estates 929 (1958); Comment, 74 HaRV. L. REv. 1191 (1961).

It appears that the problem of taxation of income of a support trust to the grantor does not ordinarily arise when the beneficiary is an adult rather than a child. Treas. Reg. $\S 1.662$ (a) -4 (1946) provides that the term "legal obligation" refers only to an obligation to support which is not affected by the adequacy of a dependent's resources. Under local law, the obligation to support an adult dependent (i.e., one's parent or other relative) is usually imposed ouly when the dependent is unable to support himself. Presumably, the definition of "Legal support" in these regulations, which specifically pertain to $\$ 662$, is also applicable to the term "legal support" as used in $\$ 677$. But see Samuels, Beware of Trusts for Dependents, 37 TaXes 1009 (1959), where the opposite conclusion is reached.

4 Sections $671,672,673,674,675 \& 678$ were created in 1954, codifying with some changes the "Clifford Regulations," Treas. Reg. 111, \& 29.22 (a)-21 (1946). Sections 676-77 of the 1954 Code are 1939 Code $\$ \$ 166-67$ respectively, with minor changes. Sections 671-78 now constitute a new Subpart E, dealing with the subject "Grantors and Others Treated as Substantial Owners."

5 For instance, the duration of the trust must be at least ten years ( $\$ 673(\mathrm{a}))$; the trust may not be revocable during the ten-year period ( $\$ 676)$; the grantor must not retain certain deailed administrative powers over the trust property ( $\$ 675$ ) ; the extent to which the grantor desires to control the beneficial enjoyment of income of the trust (i.e., to 
Clifford trust, however, which relate to matters not specifically covered by the Clifford code sections. Among the most perplexing of these matters is the extent to which the nature of property selected as corpus of the trust will affect the desired tax results. The Clifford sections themselves appear to impose no limitations upon the kinds of assets which can be utilized for trust corpus. Nevertheless, significant problems are encountered in achieving the desired tax results when certain types of property are used.

This Article discusses the problems encountered when assets of the grantor's unincorporated business are used as corpus. Such use is ordinarily accomphished in one of two ways: (1) the trust may be given an undivided interest in the business, i.e., a partnership interest, or (2) specific assets froin the business may be transferred to the trust and leased back to the grantor's proprietorship or partnership.

\section{PARTNERSHIP INTERESTS}

The reduction in total family income tax derived by use of a Clifford trust results from allocating a portion of total family income to a family member other than the primary incoine producer. The same general objective can be achieved by use of a family partnership. If ownership of the business which produces income for the family can be divided among the family inembers, some portion of total income will be taxable to individuals in income tax brackets which are lower than that of the primary imcome producer.

Early cases dealing with attempts to shift income among family members apphied the same general principles to the family partnership and the family trust. These were: income derived from personal services or efforts is taxable to the individual rendering the service, and the tax incidence of such income cannot be shifted by an anticipatory assignment of the income; ${ }^{6}$ income from capital is taxable to the owner of the capital; ${ }^{7}$ and the practical realities rather than the legal form of family transfers will determine the tax consequences, so that a purported transfer of capital will not be recognized for tax purposes when substantial elements of dominion and control over the property are retained by the alleged transferor. 8

sprinkle among beneficiaries, to accumulate, or distribute), must be correlated with the extent of independence of the trustee (i.e., is the trustee the grantor, his wife, or an independent party?) ( $\$ 674)$.

${ }^{6}$ See Lucas v. Earl, 281 U.S. 111 (1930); Burnet v. Leininger, 285 U.S. 136 (1931).

7 Blair v. Commissioner, 300 U.S. 5 (1936).

8 Helvering v. Clifford, 309 U.S. 331 (1940). Partnership cases prior to Commissioner v. 
Soon, however, the course of the law governing taxation of family partnerships diverged from that controlling family trusts. After 1940, the emphasis set by Helvering v. Clifford ${ }^{9}$ was upon the grantor's retention of dominion and control over trust corpus or income. The ultimate decision as to whether excessive control had been retained by the grantor was to be niade after measuring all of the incidents of controladministrative powers and reversionary interests retained, independence of trustee, and revocability - with no one factor controlling. ${ }^{10}$ This subjective criterion inposed by the Clifford case was found too difficult for practical application and was replaced, initially by detailed regulations ${ }^{11}$ and later by code provisions. ${ }^{12}$ The current standards used for determining the vahdity of the Clifford trust are highly specific, detailed, and generally very objective.

In the law of family partnerships the inportant departure from the general primciples indicated above came with Commissioner v. Tower, ${ }^{13}$ in 1946. This case was interpreted by the lower courts to preclude the effective formation of family partnerships unless the new partner either performed significant services for the partnership or furnished capital originating with him, as opposed to capital derived by gift from another family member. ${ }^{14}$ This doctrine requiring "original capital" or "vital services" was, as later recognized, ${ }^{15}$ a distortion of the principle requiring

Tower, 327 U.S. 280 (1946), freely applied the general doctrine of the Clifford case to family partnerships. See, e.g., Armstrong v. Commissioner, 143 F.2d 700 (10th Cir. 1944).

- 309 U.S. 331 (1940).

10 The Court stated: "Our point here is that no one fact is normally decisive but that all considerations and circumstances of the kind we have mentioned are relevant to the question of ownership and are appropriate foundations for findings on that issue. Thus, where, as in this case, the benefits directly or indirectly retained blend so imperceptibly with the normal concepts of full ownership, we cannot say that the triers of fact committed reversible error when they found that the husband was the owner of the corpus. . . "Id. at 336.

11 Treas. Reg. 111, § 29.22 (a)-21 (1946).

12 INT. Rev. CODE OF $1954 \$ \$ 671-78$.

13327 U.S. 280 (1946).

14 See, e.g., Zander v. Commissioner, 173 F.2d 624 (5th Cir. 1949); Simmons v. Commissioner, 164 F.2d 220 (5th Cir. 1947); Thorrez v. Commissioner, 155 F.2d 791 (6th Cir. 1946).

15 The Report of the House Ways and Means Committee on $\S 340$ of the 1951 amendment included the following: "Two principles governing attribution of income have long been accepted as basic: (1) income from property is attributable to the owner of the property; (2) income from personal services is attributable to the person rendering the services. There is no reason for applying different principles to partnership income. . . .

"Although there is no basis under existing statutes for any different treatment of partnership interests, some decisions in this field have ignored the primciple that income from property is to be taxed to the owner of the property. Many court decisions since the decision of the Supreme Court in Commissioner v. Culbertson ... have held invalid for tax purposes family partnerships which arose by virtue of a gift of a partnership interest from one member of a family to another, where the donee performed no vital services . . .." H. REP. No. 586, 82d Cong., 1st Sess. 32 (1951). 
attribution for tax purposes of income from capital to the owner of the capital, regardless of the source of the capital. The Supreme Court attempted to clarify its position in Tower by its 1949 decision in Culbertson v. Commissioner. ${ }^{16}$ The case did not resolve the confusion, however, and Congress responded by adopting the family partnership code provisions in $1951 .{ }^{17}$ The 1951 amendment, which was incorporated without change in the 1954 Code ${ }^{18}$ rejected the requirement of "original capital" or "vital services," and affirmed the validity for tax purposes of a family partnership based upon ownership of capital by a family member who performed no substantial partnership service, even where the capital had been derived by gift from an existing partner.

The 1951 amendment did not, however, deal with the extent to which a family partnership would fail because of intra-family controls retained by the donor of the interest. ${ }^{10}$ Culbertson had declared that the validity of the family partnership was to be determined as a factual matter. The finder of fact was to determine, from all of the circumstances, whether the parties "really and truly"20 intended to create a partnership, or whether their transaction was one of form only, designed to achieve a tax effect and no more. In rejecting the "original capital" and "vital services" doctrine Congress in no way rejected the Culbertson test of the bona fides of the intent of the parties, ${ }^{21}$ as determined from all of the

16337 U.S. 733 (1949).

17 Section 340 of the 1951 Revenue Act, inserting new $\S 191$ of the 1939 Internal Revenue Code.

18 Irt. Rev. Code of 1954 § 704(e). The Senate Finance Counmittee report on the 1954 Code provides simply: "Subsection (e) contains the family partnership provisions formerly found in sections 191 and 3797 (a)(2) of the 1939 Code."

19 An insight into the purpose and effect of the 1951 amendment is provided by the court in Stanback v. Commissioner, 271 F.2d 514, 518 (4th Cir. 1959): "In 1951, Congress legitimized family partnerships. To partnerships in which capital is a material income producing factor, it apphed the basic rule of Blair v. Commissioner. If one owns an interest in such a partnership he must be recognized as a partner though he acquired the interest as a gift, but partnership earnings may be reallocated to attribute reasonable compensation and a proportionate capital return to the donor of the interest.

"Though the Congressional Committees expressed the opinion that the statute was a declaration of existing law, they made it clear it was an application of the principle tliat income from property should be attributed for taxation to the owner of the property. It was not a codification of the Culbertson rule [337 U.S. 733 (1949)], as generally applied in the lower courts, for that rule was concerned with the recognition of partnership agreements, not with the taxation of investment income to the owner of the investment."

20 Culbertson v. Commissioner, 337 U.S. 733, 741 (1949).

21 The House Report on the 1951 amendment indicated: "The amendment leaves the Commissioner and the courts free to imquire in any case whether the donee or purchascr actually owns the interest in the partnership which the transferor purports to have given or sold him. Cases will arise where the gift or sale is a mere sham. Other cases will arise where the transferor retains so many of the incidents of ownership that he will continue to be recognized as a substantial owner of the interest which he purports to have given away, as 
circumstances. The validity of family partnerships, therefore, is still measured by subjective test, not unlike that required for family trusts by the Clifford case prior to the 1954 Code.

And so the trap for the Clifford planner is set. Because the Clifford sections identify and detail the segments and degrees of property interests whicl can be retained by a grantor, the trust is framed about and around them, carefully, so as not to violate any of the prohibitions. If a partnerslip interest is to be used as the corpus of the Clifford trust, the planner may assume that a provision permissible under the trust sections will also be permissible for family partnership purposes.

It is abundantly clear, however, that in adopting the Clifford sections in 1954 Congress did not intend to change the existing rules governing family partnerships. ${ }^{22}$ Before the partnership interest can be successfully utilized as the corpus of the trust, therefore, it will be necessary to ineasure each of the incidents of ownership and control retained by the grantor, not only in the light of the objective tests of the Clifford sections, but with a view to the subjective rules of family partnership taxation as well. Specific trust attributes commonly sought by grantors which may be unavailable when a partnership interest is used as corpus are: (1) designation of the grantor or a person amenable to his will as trustee; (2) retention of a reversionary interest; and (3) adoption of provisions designed to avoid interference with existing business management and continuity.

\section{A. Designation of Trustee}

The Supreme Court has stated ${ }^{23}$ that the essential test of validity of a family partnership is "whether, considering all the facts-the agreement, the conduct of the parties in execution of its provisions, their statements, the testimony of disinterested persons ... - the parties in good faith and acting with a business purpose intended to join in the present conduct of the enterprise." The admission of a new partner into a partnership ordinarily involves the injection of a new personality into management, a division of existing responsibility and control. When an independent party becomes trustee of a partnership interest, and hence a partner in the

was held by the Supreme Court in the analogous trust situation involved in the case of Helvering v. Clifford (309 U.S. 351). The same standards apply in determining the bona fides of alleged family partnerships as in determining the bona fides of other transactions between family members." H. ReP. No. 586, 82d Cong., 1st Sess. 32 (1951).

22 S. REP. No. 1622, 83rd Cong., 2nd Sess. 365 (1954) states, with reference to the new Subpart $\mathrm{E}$ containing the Clifford sections: "Thus, this subpart has no application in situations involving assignments of future income to the assignor ... . nor are the rules as to family partnerships affccted by this subpart." The same language is included in H. REP. No. 1337, 83rd Cong., 2nd Sess. 212 (1954).

28 Culbertson v. Commissioner, 337 U.S. 733, 742 (1949). 
business, ${ }^{24}$ it is to be presumed that such a realignment of control and management will occur, and this will be indicative of the actual intent on the part of the grantors in trust to create a genume partnerslip. Hence, the designation of an independent trustee for a family partnerslip interest is always indicative of the bona fides of the partnerslip, ${ }^{20}$ particularly if the trustee then takes an active role in partnerslip affairs. ${ }^{20}$

24 In Hanson v. Birmingham, 92 F. Supp. 33 (D. Iowa 1950) it was held that a trustee could not, under local law, be a partner, and therefore could not be treated as a partner for federal tax purposes. This position was refuted by the Tax Court in Theodore D. Stern, 15 T.C. 521 (1950). The Stern case has been cited for this proposition and followed with approval by many subsequent cases involving trust partners. See Louis $R$. Eisenmann, 17 T.C. 1426 (1952) and the cases cited therein at 1434. It would appear that the matter is no longer at issue, and that planners can proceed upon the assumption that the family trust will not be challenged upon this basis. Treas. Reg. § 1.704-1(e) (2)(viii) (1956) specifically provides for the recognition of trustees as partners of family partnerships. Cf. Rev. Rul. 58-243, 1958-1 Cum. Bull. 255 (1958), which provides that a partnership consisting of a husband and wife may be recognized for tax purposes even though under the terms of local law the parties cannot legally be partners. In Wofford v. Commissioner, 207 F.2d 749 (5th Cir. 1953) the court upheld the Tax Court's refusal to recognize the trust as a partner, but nevertheless required allocation of a portion of the partnership income to the trust because of the undenied ownership by the trust of a capital interest in the partnership. The net result appears to be recognition by the court of something of a non-statutory limited partnership. This concept has not been adopted by any other court. In Jack Rose, 24 T.C. 755, 772 (1955) the Tax Court, in distinguishing the Wofford case, said "whatever may be thought of the correctness of that decision, the situation there presented was different from the one before us."

25 For examples of cases in which the factor of the independence of the trustee was important to the recognition of the partnership for tax purposes, see Walberg v. Smyth, 142 F. Supp. 293 (N.D. Cal. 1956) (attorney as trustec); Louis R. Eisenmann, 17 T.C. 1426 (1952) (trustee was a third party-a business associate of the donor); Herbert Shainberg, 12 CCH Tax Ct. Mem. 201 (1953) (an independent attorney and accountant served as trustees); Charles C. Parks, 11 CCH Tax Ct. Mem. 761 (1952) (bank scrved as trustee); John J. Cunningham, 10 CCH Tax Ct. Mem. 800 (1951) (trustees were an attorney and an accountant). This factor alone is not, of course, decisive. See Solomon v. Commissioner, 204 F.2d 562 (4th Cir. 1953), where the trustec, although an independent bank, was so restricted as to its exercise of powers as a partner that the court found no bona fide partnership to have been crcated.

26 See, e.g., Louis R. Eisenmann, 17 T.C. 1426, 1434 (1952): "we have found that the trust was intended to be a bona fide partner, that the trustee brought credit facilities and business contacts theretofore unavailable to the business, that the trustee assisted in formulating the policies for the business, and that the trustee actively participated in the conduct of the business." It is to be noted that no particular distinction is made in the authority cited here and in the notes which follow upon the basis of the date of the decision. This failure to segregate cases by date is deemed proper for determining the bona fides of the partnership even though the citation of such authority for other purposes would require definite time categorization. The typical categories used in citing family partnership cases are: (1) PreTower cases, uneaning those decisions rendered prior to the decision of the Supreme Court in Tower in 1946; (2) cases relying upon Tower as primary authority, which will bave been decided after Tower in 1946 but before the Culbertson decision in 1949; (3) cases relying upon Culbertson as authority, which are cases decided after 1949 and dealing with tax years prior to 1951 (hence some of these cases were decided in the 1950's); and (4) cases determining issues which arose in tax years from 1951 to the present. The primary concern 
Many family partnerships have been upheld even though the donorpartner designates himself or an individual under his control as trustee of the donee's interest. ${ }^{27}$ Nevertheless, it can not be doubted that the independence of the trustee weighs heavily among the factors considered in making the subjective determination of partnership validity. ${ }^{28}$ Where the donor or a person under his control is to be the trustee, therefore, recognition of the partnership will depend upon absence of other controls and restraints, and upon strict observance of the trustee-partner's fiduciary obligations. ${ }^{29}$

of Tower, Culbertson, and the 1951 amendment, as has been previously indicated, is the question of the necessity of "original capital" or "vital services." Insofar as a test of the overall bona fides or vahidity of the partnership is concerned (other than the determination by the standards of "original capital" and "vital services"), and particularly insofar as this test is affected by the use of a trustee as a partner, the law appears not to have been changed materially by the Supreme Court cases in the 1940's and the 1951 amendment. At least two sets of cases are reported in which the same partnership arrangement is measured under the authority of Culbertson or Tower, and then measured again for subsequent years under the authority of or influence of the 1951 amendment. The decision as to validity of the partnership agreement in both cases is changed; the same partnership which was found for early years to have been invahd for tax purposes was determined bona fide for later years. See Stanback v. Robertson, 183 F.2d 889 (4th Cir. 1950) (deahing with the year 1941) and Stanback v. Commissioner, 271 F.2d 514 (4th Cir. 1959) (dealing with the years 1943-49); Smith v. Westover, 237 F.2d 201 (9th Cir. 1956) (dealing with the year 1943) and Jack Smith, 32 T.C. 1261 (1959) (dealing with the years 1952-53). In both sets of eases, however, the influence of the "original capital" and "vital services" doctrine, and the decline of this doctrine after the 1951 amendment, seem to be responsible for the shift in the decisions.

27 The following eases are exemplary of those in which the partnership is upleeld even though the trustee is not independent: Pike v. Umited States, 231 F.2d 688 (9th Cir. 1956) (donor's wife is trustee); Miller v. Commissioner, 203 F.2d 350 (6th Cir. 1953) (parentdonors are trustees); Maiatico v. Commissioner, 183 F.2d 836 (D.C. Cir. 1950) (wife is trustee, but is chosen only after independent trustee's dechine to serve); Armstrong v. Commissioner, 143 F.2d 700 (10th Cir. 1944) (donor is trustee); Drechsler v. United States, 161 F. Supp. 319 (S.D.N.Y. 1958) (partners serve as trustees for other partners' children); Broide v. United States, 156 F. Supp. 12 (N.D. Ill. 1957) (sister-in-law of donor is trustee); Goldberg v. United States, 152 F. Supp. 259 (E.D.N.Y. 1957) (brother-in-law of donor is trustee); Robert P. Scherer, 3 T.C. 776 (1944) (wife of donor is trustee).

28 The following are cases in which the lack of an independent trustee contributed to a finding of no bona fide partnership: Smith v. Westover, 237 F.2d 201 (9th Cir. 1956) (donor is trustee) ; Boyt v. Commissioner, 209 F.2d 839 (8th Cir. 1954) (donors are trustees); Feldman v. Commissioner, 186 F.2d 87 (4th Cir. 1950) (brother of donor is trustee); Stanback v. Robertson, 183 F.2d 889 (4th Cir. 1950) (each brother-partner is trustee for the other's child); Zander v. Commissioner, 173 F.2d 624 (5th Cir. 1949) (donor is trustee); Jack Rose, 24 T.C. 755 (1955) (donor is trustee); Theodore Koppelman, $10 \mathrm{CCH}$ Tax Ct. Mem. 1208 (1951), af'd, 199 F.2d 955 (3d Cir. 1952), af'd on rehearing, 202 F.2d 955 (3d Cir. 1953) (donor is trustee).

29 This point is exemplified by the following statement in Jack Smith, 32 T.C. 1261, 1269-70 (1959), where the parent-donors were the trustees of their children's trusts: "In these family partnership cases the donor parents often are, as respondent suggests in the instant case, in a position to impose their will as parents, and reduce what appears to be a gift, to a mere sham. This is especially true when the donees are young children. The conduct of the parties is to be closely scrutinized to see if the parents treated all the related transac- 


\section{B. Retention of Reversionary Interest}

Perhaps the most typical single attribute of the Clifford trust is the retention by the grantor of a reversionary interest-usually following a ten-year trust term. A prime benefit of the trust is the opportunity it offers for the temporary transfer of capital. The concept of ownership of capital for limited periods-for life or for a tern of years-is traditional in the framework of property and trust transactions. It is fair to say, however, that the admission of an individual into a partnership for a tern of years is not a typical transaction. A partnership may be created for the accomphishment of a specific venture and the members may agree to disband upon the completion of the enterprise. But seldom do nnembers of a continuing partnership agree to admit a partner for ten years only. Thus, the creation of a partnership interest to be held in trust for a period of years, with a reversion to a donor-partner, appears to be a colorable transaction.

There are many cases in which recognition of the family partnership by the court has been the result, at least in part, of a finding of the intent on the part of the donor-partner to create a permanent partnership arrangeinent..$^{30}$ Although there is no case directly in point, it would appear that the arbitrary limitation of the duration of the partnership interest to a period of years would be a major impediment to the recognition of the partnership for tax purposes. ${ }^{31}$

tions as creating, in reality, bona fide gifts of the partnership interest. Here the record shows the parents' general recognition of the trusts as owners of partnership interests; their disclosure to the partnership customers, creditors and bank that the trusts were partners; the fact that they filed notice under fictitious name statutes that the trusts were partners; a recognition of the trusts as partners in the partnership returns; the proper distribution of the partnership profits to the trusts as partners; . . . ."

See also Treas. Reg. \$ 1.704-1(e)(2) (vii) (1961), which discusses the importance of the factor of trustee independence to the recognition of a trustee as partner of the family partnership: "Where the grantor (or person amenable to his will) is the trustee, the trust may be recognized as partner only if the grantor (or sucl other person) in his participation in the affairs of the partnership actively represents and protects the interests of the beneficiaries in accordance with the obligations of a fiduciary and does not subordinate such interests to the interests of the grantor."

${ }^{30}$ See, e.g., Pike v. Umited States, 231 F.2d 688 (9th Cir. 1956); Maiatico v. Commissioner, 183 F.2d 836 (D.C. Cir. 1950); Edward D. Sultan, 18 T.C. 715 (1952), aff'd, 210 F.2d 652 (9th Cir. 1954); Louis R. Eisenmann, 17 T.C. 1426 (1952).

31 In Boyt v. Commissioner, 209 F.2d 839 (8th Cir. 1954), the donors retained a reversion in the partnership interest transferred to their children's trust, contingent upon the death of the children without issue prior to the death of the donors. Although other aspects of the case appear more important to the decision, the court mentions the retention of the reversionary interest as one of the factors leading to its conclusion that "the grantors did not accomplish, for tax purposes, the intended gift." Id. at 844. A similar reversionary interest was retained by the donors in Henry S. Reddig, 30 T.C. 1382 (1958). Again, however, the existence of the reversionary interest is merely one of many factors supporting the court's finding of no bona fide partnership. Comment, $15 \mathrm{~J}$. TAXATION 50 (1961) indicates that the 


\section{Interruption of Business Continuity and Management}

The typical partner in an ordinary partnership takes an active role in the business, asserts his own management philosophy, is personally responsible for partnership action, and has discretionary power along with other partners concerning use of partnership assets. The planner who initiates family tax planning with a trust in mind, however, will often first consider the attributes desired of his trustee. A trustee normally deals with investment properties requiring relatively little personal supervision; he is expected to conserve rather than speculate. The usual candidate for the post is a bank, trust company, or lawyer.

If such a trustee is designated it is likely that neither the trustee nor the existing partners will favor the trustee's assumption of actual partnership discretion and responsibility. The tendency will be to include, either in the trust or the partnership agreement, various limiting provisions. Exclusive power to control and manage the partnership business may be given to the existing partners; ${ }^{32}$ the trustee may be precluded from withdrawing incone or capital from the partnership without the consent of the other partners; ${ }^{33}$ the trustee may be prohibited from selling or encumbering his interest; ${ }^{34}$ and the right to replace the trustee may be retained by the donor-partner. ${ }^{35}$ Such restrictions upon the trustee's powers, although not inconsistent with the Clifford code sections, are incompatible with the concept of an actual, "bona fide," and "really and truly" partnership..$^{36}$ The failure of a great many family partnerships to achieve the tax objective souglit can be attributed to excessive restrictions imposed upon the trustee, which irreparably damage the busimess image of the partnership into which the trustee is admitted.

Commissioner in unpublished rulings has held that the retention of a reversionary interest by the donor of a partnership interest in trust would, in and of itself, be sufficient grounds to tax the partnership income to the donor.

32 See, e.g., Solomon v. Commissioner, 204 F.2d 562 (4th Cir. 1953); Kohl v. Commissioner, 170 F.2d 531 (8th Cir. 1948).

33 See, e.g., Boyt v. Commissioner, 209 F.2d 839 (8th Cir. 1954); Stanback v. Robertson, 183 F.2d 889 (4th Cir. 1950); Henry S. Reddig, 30 T.C. 1382 (1958); Theodore Koppelman, 10 CCH Tax Ct. Mem. 1208 (1951), aff'd, 199 F.2d 955 (3rd Cir. 1952), aff'd on rehearing, 202 F.2d 955 (3rd Cir. 1953).

34 See, e.g., Kohl v. Commissioner, 170 F.2d 531 (8th Cir. 1948); Fred M. Harvey, 21 T.C. 1020 (1954), aff'd, 227 F.2d 526 (6th Cir. 1955).

35 See, e.g., Fred M. Harvey, 21 T.C. 1020 (1954), aff'd, 227 F.2d 526 (6th Cir. 1955).

36 See Treas. Reg. $\$ 1.704-1$ (e)(2)(ii)(a)-(d) (1961), which describe retained controls essentially the same as those described in the text, indicating such retained controls to be "of particular significance" in determining whether a donor should be treated as remaining the substantial owner of an interest purportedly transferred to the partnership. Cf. Mim. 6767, 1952-1 CUDr. BULI. 111, 114, emphasizing the importance of the existence of controls retained by the donor in determining the validity for tax purposes of the transfer of a partnership interest. This mimeo was written to elarify the Bureau position with respect to family partnerships for years prior to 1951 . 


\section{Limited Partnership Interests}

Special consideration should be given to the possible advantages of using an interest in a hmited partnership as corpus of a Clifford trust. The relation of a himited partner to the partnership and to the general partners is by definition markedly different from that of the ordinary partner. The limited partner must take no part in the direction of the business, is limited as to the losses which he may incur, and is expected to earn a profit solely from his investment rather than from any services rendered. ${ }^{37}$

The admission of a limited partner to the partnership ordinarily does not result in any measurable change in the actual operation or inanagement of the busimess. Hence, the major test used to determine the tax validity of the general partnership-the extent to which actual control and management of the partnership is altered by the transferis inapplicable in determining the validity of the limited partnership.

The Treasury Department, while recognizing the possibility of a bona fide transfer of a limited partnerslip interest to a family member, has been unable to formulate clear guides for measuring the validity of the transaction. ${ }^{38}$ The Department has made no attempt to correlate the combined effect of the transfer to a family inember of a limited partnership interest and the creation of a trust to hold title to the interest.

Cases dealing with transfers of limited partnership interests in trust appear to measure no more than the actuality of the transfer of the capital interest. ${ }^{39}$ If a transfer has in fact been made, the limited partner-

37 Uniform Lamted Partnership Act $\S \S 4,7,9,10$; Crane, Partnership 110-11 (2d ed. 1952).

38 Treas. Reg. $\S 1.704-1$ (e)(2)(ix) (1961) provides that the recognition of a donee's interest in a limited partnership will depend on whether the donee "has acquired dominion and control over the interest. ..." The absence of services and participation in management by the limited partner will be immaterial in coming to this conclusion. Only one restriction is specifically mentioned by the Regulations as being incompatible with a bona fide limited partnership: a substantial restriction upon the limited partner's right to liquidate or transfer his interest. Cf. Mim. 6767, 1952-1 Cons. BuLL. 111, 120, which provides: "There can be no hard and fast rule as to the recognition of limited partners. The incidents of any limited partnership depend in part upon the nature of the agreement or himited partnerslup certificate and the respective rights and interests of general and limited partners as there provided for. The tests prescribed above should be applied in the light of the incidents of the relation under the applicable himited partnership statute, the provisions of the partnership agreement or certificate, and all the facts of the particular case."

39 For eases in which the family limited partnership interest is recognized, see Theodore D. Stern, 15 T.C. 521 (1950); West v. Commissioner, 214 F.2d 300 (5th Cir. 1954); Thomas H. Brodhead, 18 T.C. 726 (1952), aff'd, 210 F.2d 652 (9th Cir. 1954); Edward D. Sultan, 18 T.C. 715 (1952), aff'd, 210 F.2d 652 (9th Cir. 1954). In Boyt v. Commissioner, 209 F.2d 839 (8th Cir. 1954), the continuing control of the busmess maintained after the transfer of a limited partnership interest was no doubt a factor contributing to the court's refusal to recognize the partnership interest. There were other important contributing factors: 
ship is upheld, notwithstanding the complete absence of any change in partnership business or management.40

The investment represented by a limited partnership interest is a capital investment in the business by one who expects to profit only from the income derived by capital. It is not unkike other capital investments, such as the investment by a shareholder in corporate stock. Therefore, in theory, no reason appears why such investment should be permanent. Though a temporary investment in a general partnership interest may appear bizarre from a busmess point of view, the temporary risk of capital via a hmited partnership interest would not seem unusual. Although there is no authority supporting the proposition, it is suggested that the limited partnership interest, if created by an actual and completed transfer, should be upheld for tax purposes even though the transfer is for a limited term.

\section{E. Partnership Interests-Conclusion}

The Chfford trust is an investment device contemplating a himited term, the passive management of assets, and detailed limitations upon the beneficial enjoyment of income. The tax validity of a family partnership interest is determined by a finding as to the actual intent to form a going business. The attributes generally associated with this intent are, by and large, imcompatible with those typically found in the Clifford trust. As a general proposition, therefore, it is unwise to attempt to use an interest in a partnership as the corpus of a Clifford trust. ${ }^{41}$ The rever-

the donor became the trustee of the interest; the donor retained the right to repurchase the interest at any time at book value; and a reversionary interest in the trust was retained by the donors. The Stanback decisions are interesting for purposes of measuring the effect of the transfer to a limited partnership, particularly in the hight of the de-emphasis of the "original capital" doctrine after 1951. In the early decision (Stanback v. Robertson, 183 F.2d 899 (4th Cir. 1950)), based upon the authority of Culbertson, the limitations placed upon a transfer of a limited partnership interest in trust were found so excessive as to invalidate the transaction for tax purposes. The Court, in its recitation of grounds for the decision, mentioned that the limited partners "performed no services, ... [and] took no part in the control or management of the business. ..." Id. at 892. The later decision (Stanback v. Counmissioner, 271 F.2d 514 (4th Cir. 1959)), dealing with the same partnership for later years, and influenced by the Congressional recognition in the 1951 amendment of the validity of a partnership interest created by a capital contribution alone, recognizes the partnership for tax purposes.

40 The plamier will be well advised, of course, to give to the limited partner-trustee at least those powers and rights which the limited partner may have under the local limited partnership statute. See UnIForar Lmited ParmnerseIP ACT \$ 10. Specifically to be avoided are limitations upon the right to transfer or liquidate the limited partnership interest, to inspect partnership books, to a formal accounting and complete information whenever reasonable, to require dissolution and winding up by court decree under the same circumstances as the general partners, and to share in the profits.

41 Accord, Wrilis, Handbook of Partnership TaXation 439 (1957). But cf. Comment, $15 \mathrm{~J}$. TAXation 50 (1961), where the general theme is that where the trust qualifies under 
sion of trust corpus to the grantor after a period of years appears to be a sufficient factor in and of itself to warrant a finding that the partnership is not valid for tax purposes.

While this conclusion may be justifiable in light of the evolution of the taxation of family partnerships, it nevertheless should not apply with equal force to limited partnerships. Though the present authority on family limited partnerships is scanty, it would appear that less risk of tax invalidity is involved in the use of the limited partnership than the general partnership interest, as the corpus of a Clifford trust.

\section{II}

\section{IEASEBACKS}

If the asset selected as corpus of the trust is property required in the grantor's business, the plan for utilizing the asset presumably will be a transfer to the trust followed by a lease of the asset back to the business. Trust income will be generated by rental payments from the business, and those rental payments will be deducted by the business as an ordinary and necessary expenses. As in the case of using a partnership interest as corpus, the tax difficulties arising from attempted implementation of this plan are likely to result from the assumption that the Clifford Code sections are unore inclusive than they are, or were ever intended to be. The planning trap in this case is the assumption that because the rental income is taxable to the trust under the Clifford sections, the rental expense is deductible to the business.

Legislative history, ${ }^{42}$ which lias been given effect in the Regulations, ${ }^{43}$ indicates that the 1954 amendments resulting in the Clifford sections were intended to have no bearmg whatsoever upon deductibihity of rents paid to Clifford trusts. In creating an effective leaseback arrangement, therefore, the extent to which the trust comphes with the 1954 rules governing Clifford trusts is irrelevant to the deduction issue-one must look instead to the body of case law governmg deductibility of rents paid to family trusts.

This law, as developed both before and after 1954, has been determined upon inany of the same considerations which before the 1954 Code

the Clifford sections it should also be deemed a partner for family partnership purposes, Although the present status of the authorities does not support this view, it must be admitted that it has great merit and desirability from the planner's standpoint.

42 S. REP. No. 1622, 83rd Cong. 2d Sess. 365 (1954): "This sub-part also has no application in determining the right of a grantor to deductions for payments to a trust under a transfer and leaseback arrangement."

43 Treas. Reg. § 1.671-1(c) (1956). 
were factors used to determine whether income of the trust should be taxed to the grantor. ${ }^{44}$

For resolution of the issue, then, several different factors must be weighed and their importance judged separately and in combination with each other, just as was the case for attribution of income from Chifford trusts before the 1954 Code. The subparts which follow discuss the various factors which have been considered by the courts, in order to determine which are controlling. ${ }^{45}$ In the last of the subparts the problem of the grantor's retention of an "equity" will be discussed-a matter which has no real legitimacy to the issue, but which creeps into the cases now and then to haunt judges, lawyers, and planners.

\section{A. Pre-Arrangement of the Leaseback}

If the transfer of corpus to the trust and the leaseback from the trust to the transferor's business are accoinplished contemporaneously, or by pre-arrangement, it can be argued that the return of the property via the lease is a condition to the purported transfer, and therefore no transfer actually occurred. The corpus was never in fact removed from the control of the transferor-all that happened was that the transferor made a promise, often gratuitous, to make monthly payments to the trust. Without a recognized transfer, rental deductions based upon the assump-

44 See White v. Fitzpatrick, 193 F.2d 398, 401 (2d Cir. 1951), in which Judge Clark, discussing the deductibility of rents paid after a family gift and leaseback, states: "[T]he question here is as to the tax consequences of a formal gift of certain income-producing properties by the husband to his wife coupled with the informal retention of administrative control-the transfer, in effect, of the right to receive income and the retention of those complex of 'use rights' which are usually compressed in the term 'ownership.' In the context of ... [\$ 23(a)(1)(A)], the question is a rather new one; under ... [\$22(a)], where it arises in the definition of gross income problems, it is not. And we think the line drawn in the precedents under the latter section is the same as that in the field of deductibility of business expenses. . . . We think, therefore, that the principles governing the intermarital transfer of income enunciated in Helvering v. Clifford ... [citation omitted] and reinforced [sic] by later cases, are also decisive here. . . . The same result should obtain whether the question arises under section 22 (a) or section 23 (a) (1)..."

45 Since the cases are to be considered only upon the basis of their discussion of specific issues, no complete historical review of them will be given. An historical analysis might well be of value, however, and the principal cases, cited in chronological" order, are therefore provided: Johnson v. Commissioner, 86 F.2d 710 (2d Cir. 1936); A. A. Skemp, 8 T.C. 415 (1947) ; Skemp v. Commissioner, 168 F.2d 598 (7th Cir. 1948), reversing 8 T.C. 415 (1947); Ingle Coal Corp. v. Commissioner, 174 F.2d 569 (7th Cir. 1949); Catherime G. Armston, 12 T.C. 539 (1949), aff'd, 188 F.2d 531 (5th Cir. 1951); Helen C. Brown, 12 T.C. 1095 (1949); Brown v. Commissioner, 180 F.2d 926 (3d Cir. 1950), reversing 12 T.C. 1095 (1949); Shaffer Terminals, Inc., 16 T.C. 356 (1951), aff'd, 194 F.2d 539 (9th Cir. 1952); White v. Fitzpatrick, 193 F.2d 398 (2d Cir. 1951); Stearns Magnetic Mfg. Co. v. Commissioner, 208 F.2d 849 (7th Cir. 1954); Albert T. Felix, 21 T.C. 794 (1954); Kirschemunann v. Westover, 225 F.2d 69 (9th Cir. 1955); John T. Potter, 27 T.C. 200 (1956); Edward F. Hall, 62-2 U.S. Tax Cas. If 9676 (N.D.N.Y. 1962) ; I. L. Van Zandt, 40 T.C. 824 (1963). 
tion that the trust owns the property must be disallowed. This theory was first formulated in an early case involving an interest deduction where a gift of money was followed by a loan of the funds back to the donor, ${ }^{40}$ and was developed in later Tax Court cases. The theory, at least in the abstract, seems quite logical and was enunciated with great clarity by the Tax Court in Helen C. Brown. ${ }^{47}$ As applied to a short-term trust, however, it has never been adopted by an appellate court. After rejection by both the Seventh and the Third Circuits, ${ }^{48}$ the Tax Court appears to have discarded the theory. ${ }^{49}$

In a recent Tax Court case, ${ }^{50}$ and a recent district court case, ${ }^{51}$ the fact of pre-arrangement of the leaseback was used not for the purpose of finding that no actual transfer was made, but as a signpost alerting the court that close scrutiny should be given to the transaction. ${ }^{62}$ It is apparent that all trust leasebacks are preconceived-a doctor certainly expects to rent the $X$-ray equipment in his office from the trust to which he donates it. Nevertheless, in the hight of these recent cases, it would appear good planning to avoid any further appearance of pre-arrangement.

A hittle reflection indicates that there is actually no reason at all why the lease need be pre-arranged. The donor can convey the property even to a coinpletely independent trustee, secure in the knowledge that he will always be the highest bidder for use of the property. All other bidders are interested in paying as low a rental as possible. The donor, however, is interested in paying as high a rental as is commensurate with going market rates, because the greater the rental the more tax benefit to the family as a unit. The donor should be interested, therefore, in obligating the trustee to ascertain the liighest price whicl can be obtamed for the property under the best of circumstances-and then paying that price or slightly better. ${ }^{63}$

46 Johnson v. Commissioner, note 45 supra.

4712 T.C. 1095 (1949).

48 Skemp v. Commissioner, 168 F.2d 598 (7th Cir. 1948), reversing 8 T.C. 415 (1947); Brown v. Commissioner, 180 F.2d 926 (3d Cir. 1950), reversing 12 T.C. 1095 (1949). But cf. White v. Fitzpatrick, 193 F.2d 398 (2d Cir. 1951).

49 The leasebacks in Albert T. Felix, 21 T.C. 794 (1954) and John T. Potter, 27 T.C. 200 (1956) were both obviously prearranged, the leasebacks being contemporaneous with and a condition to the transfers to the trust. In neither case, however, did the Tax Court mention this as a factor having any bearing on the matter.

50 I. L. Van Zandt, 40 T.C. 824 (1963).

51 Edward F. Eall, 62-2 U.S. Tax Cas. If 9676 (N.D.N.Y. 1962).

52 See also Rev. Rul. 54-9, 1954-1 Cum. Butr. 20 (1954).

53 Care must be taken, however, not to establish a price which is higher than the economics of the situation warrant. See, e.g., dicta in Consolidated Apparel Co. v. Commissioner, 207 F.2d 580 (7th Cir. 1953); Riverpoint Lace Works, Inc., 13 CCH Tax Ct. Mem. 463 (1954). 


\section{B. Independence of Trustee}

In Skemp and Brown, ${ }^{54}$ the two leading circuit court decisions in which the taxpayer was allowed to deduct rents paid the trust, a trustee other than the grantor was used. Van $Z_{a n d t}{ }^{55}$ a recent Tax Court case which disallowed the rent deduction on facts similar to those in Skemp and Brown, distinguished those cases on the ground that independent trustees were used. Other cases subsequent to Skemp and Brown, and similar to Van Zandt except for the grantor's use of an independent trustee, have resulted in victory for the taxpayer. ${ }^{56}$

This emphasis upon the independence of the trustee would seem at this date a little misplaced. ${ }^{57}$ The history of the Chfford principle, culminating in the 1954 Code, envisages the donor's acting as his own trustee without invalidating the trust for tax purposes. Although it is acknowledged that the Clifford sections are not determinative for leaseback rental deduction purposes, the logic behind the permissiveness of the income sections should have some influence on the deduction issue. Further, although "independence" of trustee is discussed as indicative of the bona fides of the transfer, no attempt is made in the cases to measure the actual mdependence of the trustee. In cases upholding the leaseback deduction, for instance, the "independent" trustees have consisted of the donor's attorney, ${ }^{58}$ as well as his wife, father, and accountant. ${ }^{50}$

The questionable validity of the distinction notwithstanding, it must be recoguized that in every case in which the taxpayer has prevailed, the trustee has been someone other than the donor; in notable cases in which the taxpayer has failed, he has designated himself as trustee. ${ }^{60}$ At this time, therefore, the only prudent course is to appoint someone other than the grantor as trustee of the Clifford trust. There seeems to be no reason, however, not to enlist the services of the grantor's brother, father, lawyer, or accountant. ${ }^{61}$

54 A. A. Skemp, 8 T.C. 415 (1947); Helen C. Brown, 12 T.C. 1095 (1949).

EE I. L. Van Zandt, 40 T.C. 824 (1963).

56 See Albert T. Felix, 21 T.C. 794 (1954); John T. Potter, 27 T.C. 200 (1956).

57 For criticism of the distinction, see Note, 65 Harv. L. Rev. 1250 (1952); Note, 51 Corusr. L. REv. 247 (1951).

68 Brown v. Commissioner, 180 F.2d 926 (3d Cir. 1950), reversing 12 T.C. 1095 (1949).

69 John T. Potter, 27 T.C. 200 (1956).

${ }^{60}$ I. I. Van Zandt, 40 T.C. 824 (1963); Edward F. Hall, 62-2 U.S. Tax Cas. II 9676 (N.D.N.Y. 1962).

61 Although it is desirable to use as independent a trustee as possible, use of a bank or trust company is seldom practicable. The relative uncertainty and novelty of the transaction repels most bankers, and even the minimum trustee's fee customarily charged by the banker will usually be too high for the comparatively low income-producing Clifford trust. 


\section{Duration and Revocability}

In the two appellate cases which are primary authority in leasebacks, Skemp and Brown, ${ }^{62}$ the grantor retained neither a power of revocation nor a reversionary interest. On termination, the trust corpus went to the beneficiaries of the trust. In Felix and Potter, ${ }^{63}$ two significant Tax Court cases which follow Skemp and Brown, and in which the taxpayer prevailed, the grantor likewise retamed neither power of revocation nor reversionary interest. In Hall and Van Zandt, ${ }^{64}$ two recent cases in which the taxpayer lost, the trusts were for ten-year terms, reversion to the grantor. Do these results mean that the rental deduction for leasebacks to family trusts will always be denied when the grantor has retained a reversionary interest or a power to revolse the trust after a ten-year period? It is suggested that this should not be the conclusion drawn from these cases.

To be sure, the courts in Skemp, Broven, and Felix all mention the point as one factor aiding in the decision that the grantor had "irrevocably divested himself of all title and right" ${ }^{\prime 35}$ to the property donated to the trust. In Hall the taxpayer lost because of a generahized finding of lack of substance in the trust leaseback transaction based upon several factors, the retention of a reversionary interest being only one factor..$^{08}$ In Van Zandt the court all but ignored the factor of the retained reversionary interest, specifically stating that the sole and adequate basis for distinguishing Skemp, Brown, and Felix was the presence of independent trustees in those cases. ${ }^{67} \mathrm{~A}$ reasonable conclusion, it seems, is that the retention of a reversionary interest by the grantor of a leaseback family trust is a factor which will be taken into consideration in weighing the bona fides of the transfer, but that by itself it is not sufficient to invalidate the transaction. Any other conclusion would preclude entirely the use of the short term trust in leaseback planning-a result which has not been suggested by any of the cases.

62 Skemp v. Commissioner, 168 F.2d 598 (7th Cir. 1948); Brown v. Commissioner, 180 F.2d 926 (3d Cir. 1950).

63 Albert T. Felix, 21 T.C. 794 (1954); John T. Potter, 27 T.C. 200 (1956).

64 Edward F. Hall, 62-2 U.S. Tax Cas. If 9676 (N.D.N.Y. 1962) ; I. L. Van Zandt, 40 T.C. 824 (1963).

65 See, e.g., Skemp v. Commissioner, 168 F.2d 598, 600 (7th Cir. 1948).

${ }^{66}$ Edward F. Hall, 62-2 U.S. Tax Cas. If 9676 (N.D.N.Y. 1962). The factors considered in concluding that the transaction had no substance were: (a) Death of a grantor or beneficiary voided the instrument, (b) retention of a reversionary interest by the grantor, (c) retention by the grantor at all times of the power to dispose of the corpus, via the leaseback, and (d) the grantor's retained power to settle the trustee's accounts.

67 I. L. Van Zandt, 40 T.C. 824,830 (1963). 


\section{Business Purpose}

Corporations are by definition totally business motivated. They do not traditionally make gifts. Where a corporation transfers property to a related entity and then leases it back, it seems proper to look to the business reasons for the transfer in determining deductibility of lease payments. If the transfer, though masquerading as business purposed, turns out to be for personal tax reasons, the sham of the transfer can be imputed to the lease as well, so that the whole transaction falls. Cases involving corporate transfers have followed this line of reasoming, in holding that leaseback rental payments are not "ordinary and necessary" when the original transfer was not made for bona fide business purposes. ${ }^{68}$

An individual, however, is governed by many non-business influences, and it is recognized that all his transfers need not be business motivated. He may, for instance, make outright gifts of income producing assets. No one has ever challenged the right of an individual to establish a Clifford trust with stock of a corporation, for instance. Similarly, there should be no problem created by a proprietor's transferring some of his business assets to his child's trust. The fact that the transaction has no business purpose has nothing to do with its bona fides-it is not intended to have a business purpose.

The proof of this analysis should be found in a situation involving a corporate transfer legitimately made for other than the profit motive. One such transfer is the distribution of dividends. In the one case precisely in point ${ }^{69}$ a patent was distributed by a corporation to its sharelolders as a dividend; the shareholders then leased the patent back to the corporation. In refuting the argnment that the lease payments should not be deductible because of lack of business reason for the original transfer, the Seventh Circuit stated:

We are not concerned with whether the declaration of dividend resulted in benefit to the company. Dividends are declared for the benefit of the stockholders and, if the corporation is solvent, they are justified. The test is not whether the dividends eventually further the corporate business purposes or not, but rather whether the license agreement requiring the payment of royalties was reasonable. ${ }^{70}$

68 Ingle Coal Corp. v. Commissioner, 174 F.2d 569 (7th Cir. 1949) (transfer resulting from partial liquidation of corporation); Catherine G. Armston, 12 T.C. 539 (1949), aff'd, 188 F.2d 531 (5th Cir. 1951) (purchase by wife of corporate property with a leaseback to corporation); Shaffer Terminals, Inc., 16 T.C. 356 (1951), aff'd, 194 F.2d 539 (9th Cir. 1952) (sale of equipment to shareholders followed by leaseback); Riverpoint Lace Works, Inc., $13 \mathrm{CCH}$ Tax Ct. Mein. 463 (1954) (sale to shareholder).

69 Stearns Magnetic Mfg. Co. v. Commissioner, 208 F.2d 849 (7th Cir. 1954).

70 Id. at 852. 
Hence, where a grantor gives business property to a minor's trust and leases it back, no inquiry should be made as to whether there was a business reason for making the gift. Admittedly there is none. The test of business necessity should be made by viewing the situation as it exists after the gift is made. At that point it is certainly necessary for the business to rent the property from the trust, and if the rental paid is reasonable, there is no basis for saying that the rent is not, in the terms of section 162, "ordinary and necessary" and "required to be made as a condition to the continued use ... of property."

Unfortunately, the cases have not been consistent in recognizing the difference between trusts created by businesses through purported business transactions and trusts of business property created by gift. The culprit most guilty of muddying the waters is Van Zandt. As authority for disregarding the leaseback after a clear gift by a father to his child, the court cites cases "where a sale and leaseback does not serve a utilitarian business purpose, but is in reality a camouflaged assignment of income. ..." It is submitted that this analysis is wrong, and that to the extent that the case rests upon this basis, it is incorrectly decided.

\section{E. Has the Donor Retained an "Equity"?}

In legal parlance one has an "equity" in property when he has a right of redemption, a reversionary interest, a right to specific performance, or in general any right respecting property which traditionally would have been enforceable by means of an equitable remedy. ${ }^{72} \mathrm{Sec}$ tion 162 (a) (3) provides that rentals are deductible only when paid for the use of property "to which the taxpayer has not taken or is not taking title or in whicl he has no equity." Does section 162 (a)(3) mean what it literally says-that no deduction will ever be allowed for the rental of property with respect to which the lessee has any right enforceable at equity? If so, no leaseback can ever effectively be made of property by the grantor of a short term trust. This result seems inconceivable; yet this prohibition of section $162(\mathrm{a})(3)$ has been used as an alternative basis for denying rental deductions in two recent cases. ${ }^{73}$

71 I. L. Van Zandt, 40 T.C. 824, 830 (1963). Cases so relied upon are Armston, Unger, Campbell, and White v. Fitzpatrick. The only case of the group involving a gift-leaseback was the White case; the opinion discusses the disadvantageous nature of the gift from the point of view of the business as something of a makeweight to its genernlized conclusion that the entire transaction was a sham. See also Rev. Rul. 54-9, 1954-1 Cums. Burc. 20 (1954).

72 See Black's Law Dictionary 634-35 (4th ed. 1951).

73 In Kirschenmann v. Westover, 225 F.2d 69 (9th Cir. 1955), a farmer purchased realty on time and then conveyed the realty, subject to the purchase agreement, to his children, leasing the property back from them. The rental paid on the leaseback was so 
This part of section 162 (a)(3) has never been amplified by regulations, nor is the legislative history any aid in ascertaining the purpose of Congress in adopting the plrraseology. ${ }^{74}$ The one phase of rental deduction litigation which has caused extensive analysis of the limitation is the issue of deductibility of rents paid by a lessee who also has an option to purchase. Although commentators discussing this subject liave noted the possible literal application of section $162(\mathrm{a})(3),{ }^{75}$ courts have not so applied the section. Rental deductions are allowed unless, from the economics of the transaction, it is found that eacli rental payment increased the ownership interest of the lessee-optionee. In other words, the courts in the lease-option cases have never been bothered by the fact that the lessee has an acknowledged equity embodied in his option. They look instead to the rental payments, to see wliether the payments

obviously exorbitant that the majority had no difficulty in denying the rental deduction because of its complete lack of busmess reality. The concurring opinion, lowever, suggested that an alternative basis for the decision was the existence of the mortgage on the property. Should the owner (the child) default in payments, and slould the mortgage be foreclosed, the grantor would then have a right of redemption, which qualifies under the literal definition of $\S 162$ (a) (3) as an "equity." Hence, the rental deduction slould be denied. In Edward F. Hall, 62-2 U.S. Tax Cas. If 9676 (N.D.N.Y. 1962), three doctors transferred a ten-year interest in realty and personalty to a trust for the benefit of children. The judge, in discussing the "equity" argument, noted that the point had not been extensively argued and no cases relative to it had been cited. He found, however, as an alternative basis for the decision, that the retention by the grantors of the reversionary interest constituted an "equity" in the property, requiring demal of the rental deduction under $\$ 162$ (a) (3). Burrouglis Corporation, 33 T.C. 389 (1959), involved a grant by a corporation to a trust for the benefit of employees. The court found that because the grantor had retained so many powers to control the trust and himit the use of corpus, it in fact remained the owner of the corpus. Hence, a charitable deduction was denied. After this finding, the court logically concluded that the grantor had retained an "equity" in the land sufficient to deny the rental deduction. The use of the word "equity" in this last case is sucl that the word "ownership" could be substituted, and it is believed that the case does not stand for approval of the literal interpretation of the word "equity" given by the concurring opimion in Kirschenmann and the trial court in Hall.

74 The pliraseology was first inserted by the Revenue Act of 1916 and has remained intact ever since. Neither the House Report (H.R. ReP. No. 922, 64th Cong., 1st Sess. (1916)), nor the Senate Report (S. Rep. No. 793, 64th Cong., 1st Sess. (1916)), gives any clue as to the purpose for adoption of the wording. Lukins, Tax Treatment of the Lease with Option to Purchase: Is Allocation the Answer?, 11 TAx L. Rev. 65 (1955), suggests that the restriction was adopted to prevent the deduction of mortgage payments. Without the added wording the mortgage payments would be payments required as a condition to the continued use of property and hence would be deductible even though a portion of the payment was made in reduction of principal. This explanation of Congressional purpose seems quite plausible, and is picked up and approved in 4 MERTENs, LAw of FEDeraI Income TAxATION $\S 25.108$ (rev. ed. 1960). The same explanation is reported by Johnson, Lessee Improvements to Leased Property and Option to Purchase, N.Y.U. 12TH INST. ON FED. TAX 75,89 (1954). The only case cited in connection with this analysis, however, is Forty-Two Broadway Co. v. Anderson, 209 Fed. 991 (S.D.N.Y. 1913), rev'd, 239 U.S. 69 (1915), which case would appear to involve the problem of an interest rather than a rental deduction.

75 See Johnson, supra note 74 ; Lukins, supra note 74. 
are in fact for "rent" or whether they in fact are for the "purchase" of the property, hence increasing the lessee-optionee's "equity."70

It is submitted that the view taken by the courts in the lease-option cases is the correct interpretation of "equity" in section $162(a)(3)$. It is entirely reasonable to preclude deductibility of a payment which is not for the temporary "use" of property, but in reality is adding to ownership equity. On the other hand, there is no justifiable reason for summarily preventing the rental of property by a person who happens to have an ownership interest in the property other than his leasehold interest. Such a rule would preclude not only the rental of property donated to a short term trust, and the rental of property subject to an option to purchase, but other practical and honestly conceived business transactions. For instance, is there any reason to prevent the lessor of a master supermarket lease from being a subtenant of the lessee in the supermarket liquor department? Should a vested remainderman be prevented from renting from the life tenant? Suppose a vendee desires to take possession of premises prior to the close of escrow. Is there any policy justification for denying deductibility to the rental payments made for the short term business lease arranged so as to allow early occupancy? The answer to all these questions must be "no."

It is suggested, therefore, that the recent literal interpretation of "equity" made in the referenced leaseback cases is not correct, and that it should be rejected.

\section{F. Conclusion-Leasebacks}

The tax consequences of a carefully planned leaseback from a Clifford trust are sufficiently predictable to permit use of the trust-leaseback as a device for income splitting among family members. In planning for the leaseback transaction care should be taken to adhere to the requirements of the Clifford sections, and the following limitations should also be observed: (1) A trustee other than the grantor must be used; (2) the leaseback should not be pre-arranged, but should be negotiated after the transfer in trust; (3) rentals paid should approximate and in no case greatly exceed the fair rental for similar property obtainable on the open market; (4) scrupulous attention to the business and trust formalities of the transaction should be observed.

It might be suggested that the Clifford trust-leaseback plan falls into the category of "What do you have to lose?" transactions. That is, since the plan attempts to lower overall family taxes by income splitting,

76 Of the many cases in this area, the following are illustrative: Breece Veneer \& Pancl Co. v. Commissioner, 232 F.2d 319 (7th Cir. 1956); Judson Mills, 11 T.C. 25 (1948); Edward E. Haverstick, 13 B.T.A. 837 (1928). 
its failure simply relegates the taxpayer to the position occupied before the attempt. The $\operatorname{Van} Z$ andt analysis might support this reasoning, since if the deduction is denied it must be concluded that the business has made a gift of the rental payment to the trust, and this gift will presumably not constitute income to the trust. ${ }^{77}$ The test for income realization by the trust, however, is not hitched to the test for deductibility of rents. It is far from clear that the non-deductible rent will not constitute trust incoine, ${ }^{78}$ particularly considering the improbability that the issues will be decided in one case. This risk, then, must be considered.

Finally, in listing the disadvantages of a failing leaseback plan, the possibility should not be discounted that though the transaction is invalid for tax purposes it will still be viable for all other purposes, and thus problems could arise in a premature attempt to terminate the arrangement. When all is said and done, it is perhaps wise to suggest that the trust idea be discarded unless the grantor has decided that he not only wants to save taxes, but is resigned in any event to making a substantial gift to his beneficiaries.

77 The same inference can be drawn from Rev. Rul. 54-9, 1954-1 CuM. BuLL. 20 (1954).

78 For discussion of this point, see Cohen, Taxation of Leasebacks to Trusts: Tax and Planning Considerations, 43 VA. L. REv. 31, 41 (1957). 